\title{
Job Satisfaction and Turnover Intention: Moderation of Organizational Trust and Organizational Justice
}

\author{
Mafizatun Nurhayati ${ }^{1}$, Luna Haningsih ${ }^{2}$, Syifa Awaliyah ${ }^{3}$ \\ ${ }^{1,2,3}$ Faculty of Economic and Business, University of Mercu Buana
}

mafizatun.nurhayati@mercubuana.ac.id

\begin{abstract}
This study aims to analyze the role of organizational trust and organizational justice in moderating the effect of job satisfaction on turnover intention. The population in this study are employees in several information technology companies in Jakarta. The research sample amounts to 195 respondents. Data collection method is done through a questionnaire. Data analysis method uses structural equation modelingpartial least square (SEM-PLS). The results of this study prove that job satisfaction a negative effect on turnover intention. Organizational trust does not affect turnover intention. The interaction of job satisfaction and organizational trust as a moderating variable affects turnover intention. Organizational justice has a negative effect on turnover intention. The interaction of job satisfaction and organizational justice as a moderating variable does not affect turnover intention.

Keywords: job satisfaction, organizational trust, organizational justice, turnover intention
\end{abstract}

\begin{tabular}{ll}
\hline JEL & $:$ M12 \\
DOI & $: 10.24002 /$ kinerja.v24i2.2419
\end{tabular}

Received : 08/14/2019 Reviewed: 03/01/2020 Final Version: 07/10/2020

\section{INTRODUCTION}

Human resources is the company's most important problem because human resources cause other resources in the company function or run. Effective human resources require managers or leaders to find the best way to empower people in the company environment so that the desired goals can be achieved (Mangkunegara, 2016). If the management is not as expected, it will cause human resource problems, one of them is turnover intention.

Turnover defines as an employee quitting a company or organization and moving to another company for a reason (Robbins \& Judge, 2015). Turnover occurs because of cognitive stages such as thoughts about quitting work, intending to find alternative work, or intending to leave work. The desire to move has a negative impact on the organization because it creates instability in labor 
conditions, decreased productivity, a non-conducive work atmosphere, besides it also affects the quality and ability to replace employees who leave the company, so it takes time and costs to recruit new employees (Martono \& Fadzilah, 2016).

By using a study of previous research, turnover intention is influenced by several variables, including job satisfaction (Pawesti \& Wikansari, 2016; Hidayati \& Trisnawati, 2016; Abdurrahim \& Anisah, 2015; Poeh \& Soehari, 2017; Soelton \& Atnani, 2018)), organizational trust (Cipta, 2016; Martono \& Fadzilah, 2016), organizational justice (Wiratama \& Suana, 2015; Suta \& Supartha, 2016), job insecurity (Martono \& Fadzilah, 2016), and several other factors.

Job satisfaction affects turnover intention. Low job satisfaction can reduce the enthusiasm to improve performance in that making the turnover rate even higher (Cipta, 2016). Job satisfaction is a specific description of someone's job (Suta \& Supartha, 2016). Employees are satisfied if the work done is appreciated by the company. Job dissatisfaction pushes employees to leave their jobs to move to another company.

In addition, employee confidence in the company can also be an important factor in determining whether or not employees survive in the company (Fadzilah \& Martono, 2016). Organizational trust arises if employees feel what is expected can be obtained while in the company. Problems that often arise is that their desires and expectations have not been reached or have not been met due to lack of attention to their employees. If the level of employee confidence in the company is lower, the higher the desire to move employees from their workplaces (Fadzilah \& Martono, 2016).

Organizational justice can also have an impact on turnover intention (Suta \& Supartha, 2016). Organizational justice as a level where an individual feels treated equally in the organization where he works (Kristanto, 2015). Several phenomena regarding organizational justice focus primarily on employee perceptions of the fairness of the results received by what has been done or the level of skills possessed by employees. Likewise, the level of expertise and skills they have do not match the results or the benefits received (salary). Injustice perceived by employees affects uncomfortable feelings such as disappointment, anger, and decreased employee morale. Employees' perceptions about these injustices encourage employees to do things as they please to the organization where they work. The forms of employee behavior for managerial injustice are delaying work, coming to work late, often absent from work and lazing when working, courage to oppose or protest to superiors, starting to violate work rules, as well as seriousness in completing responsibilities which in turn can affect the desire to leave the job.

Previous studies have found that job satisfaction negatively affects turnover intention (Hidayati \& Trisnawati, 2016; Pawesti \& Wikansari, 2016; Abdurrahim \& Anisah, 2015; Cipta, 2016; Wiratama \& Suana, 2015; Suta \& Supartha, 2016; Iqbal et al. 2016 ., 2014; Saeed et al., 2014). But the research of Yuda \& Ardana (2017) found that job satisfaction does not affect the desire to leave the job. Here we find different research results, for this reason, this research gap needs to be filled so that the novelty of this research is found. 
To fill the research gap, first, the researcher examines that there is a possibility in an organization that job dissatisfaction has a stronger impact on the desirability of employees to leave the job when there is no trust of members to the organization. Organizational trust in this case has the role of weakening the influence of job dissatisfaction on employee desires. In line with the social exchange theory introduced by Blau in 1964 (Farooq et al., 2014) that if a member of an organization gets what he expects by entering the organization, they will respond by showing a positive attitude, and vice versa, if trust to organizations low, it will encourage organizational members to leave the organization (Zevane \& Melhem, 2017). To fill the second research gap, the researcher examines that job dissatisfaction is possible to have an impact on strengthening the desire to leave employees, when job dissatisfaction is strengthened by the presence of injustice in the organization. Organizational justice in this case has a role to moderate the effect of job satisfaction on employee desires.

Based on the phenomenon of the problem above, it is interesting to study the role of organizational trust and organizational justice in moderating the effect of job satisfaction on turnover intention in several information technology companies in Jakarta. It is expected that the results of this study can provide information in overcoming the level of turnover intention and in making new policies relating to job satisfaction, organizational trust and organizational justice, and contributing to knowledge, specifically related to concepts about job satisfaction, organizational trust, organizational justice and turnover intention.

\section{LITERATURE REVIEW}

\subsection{Turnover Intention}

According to Wirawan (2015) turnover intention is the tendency or intention of employees to stop working from work voluntarily according to their own choice. Meanwhile, according to Robbins \& Judge (2015) turnover intention is a situation where workers have intentions or tendencies done consciously to look for other work as an alternative in different organizations, the desire to move can be an early symptom of turnover in a company.

\subsection{Job Satisfaction}

Robbins \& Judge (2015) state that job satisfaction is the way a person feels about himself or his work. This shows that job satisfaction is a feeling that supports or does not support in oneself related to work or perceived conditions. According to Cipta (2016), someone who has high job satisfaction will take positive actions towards his work, otherwise people who are dissatisfied will show negative actions. According to Pawesti \& Wikansari (2016) job satisfaction influences a person's desire to leave the organization, the process of leaving from a company begins with an increase in job dissatisfaction. Workers who are dissatisfied with their work tend to do things that can interfere with organizational performance: high turnover, high absenteeism, inaction at work. Employee turnover tends to be lower, if 
employee satisfaction is high and vice versa if employee turnover tends to be higher, it is due to low employee satisfaction.

The statement is strengthened by the results of research by Pawesti \& Wikansari (2016) which shows that the relationship of job satisfaction and turnover intention is a negative relationship, if job satisfaction is high, turnover intention will be low. If job satisfaction decreases, turnover intention will increase. Abdurrahim \& Anisah (2015), Hidayati \&Trisnawati (2016), and Sartika (2014) find that job satisfaction has a negative effect on turnover intention, if employees feel dissatisfied with their work then employee turnover will increase.

$\mathrm{H} 1$ : Job satisfaction has a negative effect on turnover intention.

\subsection{Organizational Trust}

According to Zalabak et al (2010), organizational trust is an important variable for organizational effectiveness. Employees who have confidence in their organizations will care about the future and success of the company and understand their role in the organization and try to do the best for their roles. Organizational trust can be a factor influencing employees' desire to change employment. An employee believes that the company will also give the best, then the employee will continue to survive in his work (Nurhayati et al., 2018). Organizations with low trust or no vulnerability to various negative responses from employees, including high withdrawal, reduced job satisfaction, reduced cooperation, and increased absenteeism can create high turnover, vice versa, the higher the trust, the lower the turnover. This statement is reinforced by the research of Martono \& Fadzilah (2016), and Cipta (2016) stating that organizational trust has a negative effect on turnover intention.

In an organization, there is a possibility that job dissatisfaction will have a stronger impact on the desirability of employees to leave the company when there is no trust in members of the organization. Organizational trust in this case has the role of weakening the influence of job dissatisfaction on employee desires. Organizational trust is the ability shown by the organization to provide commitment to its employees (Nurhayati et al., 2018). The relationship between the individual and the organization begins with building trust first with the organization, then these feelings are developed and manifested in the form of strong attachments and personal identification in the organization. The existence of these attachments, despite dissatisfaction, can have an impact on the survival of employees in an organization.

H2: Organizational Trust negatively affects turnover intention.

$\mathrm{H} 3$ : Organizational trust plays a role in moderating the effect of job satisfaction on turnover intention.

\subsection{Organizational Justice}

According to Wiratama \& Suana (2015), organizational justice is a treatment, and actions received by each employee regardless of status or position and can be said to be fair if employees get their rights in accordance with what they contribute 
to the company. Robbins \& Judge (2015) state that organizational justice is a level where an individual feels treated equally in the organization where he works.

Hwei \& Santosa (2012) say that assessing organizational justice has an impact on employee attitudes and reactions. When employees are treated fairly, they will behave as needed for the successful of the organization even in difficult conditions. According to Wiratama \& Suana (2015), a leader needs to consider the principles of justice when making decisions because members of the organization have a strong sensitivity to justice around them. If an employee feels treated fairly, he will feel satisfied and will never think of leaving the organization. The results of research by Suta \& Supartha (2016), Wiratama \& Suana (2015) prove that organizational justice has a negative effect on employees' desire to leave the company.

In addition, it is also possible that job dissatisfaction can have an impact on reinforcing the desire to leave employees, when job dissatisfaction is strengthened by the presence of injustice in the organization. Organizational justice plays a role in moderating the effect of job satisfaction on turnover intention.

H4: Organizational Justice has a negative effect on turnover intention.

$\mathrm{H} 5$ : Organizational justice plays a role in moderating the effect of job satisfaction on turnover intention.

\section{METHODOLOGY}

\subsection{Research Design Data Collecting Design}

The approach of this research is the causal method. This study examines the role of organizational trust and fairness in moderating the influence of job satisfaction on the desires of employees working out. This research was conducted on employees of several information technology companies in Jakarta. The research instrument used a questionnaire of 195 research respondents.

\subsection{Variable Measurement}

Turn over intention is the mind of individuals in an organization to get out of the organization, the desire to find other job, and the desire to leave the organization in the foreseeable future. According to Chen \& Francesco (2000), the measurement of turnover intention is measured by indicators of the mind to leave the organization, the desire to find other job openings, and the desire to leave the organization in the coming months.

Job satisfaction is a feeling that supports or does not support in oneself related to work or perceived conditions. Job satisfaction is measured using Tsai's (2008) measurement, with indicators of compensation, supervision, work itself, relationships with colleagues, working conditions, opportunities for status changes, and job security.

Organizational Trust is the willingness of an organization based on culture and behavior to be vulnerable to individuals, groups, or other organizations on the basis of beliefs. This study uses the measurement by Shockley-Zalabak et al. 
(2000) stating that they are competent, or various variables that arise in communities are open and honest, caring, reliable, and identified with goals, norms, and values.

Organizational Justice has an impact assessment on employee attitudes and reactions, when employees are treated fairly. Organizational justice is measured using the measurement of Hwei \& Santosa (2012), with indicators of distributive, procedural and interactional justice.

In the operationalization, all scales are measured by five Likert points (from 1 $=$ very unlikely to $5=$ very likely) or (from $1=$ strongly disagree to $5=$ strongly agree) (Malhotra \& Birks, 2007).

\section{RESULT AND DISCUSSION}

\subsection{Respondent Description}

Respondent characteristics discussed in this study are gender, age, last education, length of work, and position. Respondents by sex showed that $69.5 \%$ are male and $30.5 \%$ are female. It can be seen that the majority of the employees who work in IT companies are male. Respondents based on age show that the highest number are respondents with ages between 26-30 years as many as $47.4 \%$ and the lowest number are respondents with ages between $>40$ years as many as $7.4 \%$. In general, employees who work for IT companies are in the productive age, which is between $26-40$ years. Respondents based on their latest education show that the highest number are respondents with a D3 education level of $48.4 \%$ and the lowest number are respondents with a high school / vocational education level of $5.3 \%$. The conclusion is that the majority of employees working in IT companies is with a D3 education level. Respondents based on the length of work, the highest number are employees who have worked for 1-5 years as much as $73.7 \%$, while the lowest number is employees who have worked for 11-15 years as much as $1.1 \%$. It is seen that the highest number of employees working in IT companies are respondents with the lenght of work for 1-5 years. Respondents based on positions, the highest number are respondents with marketing positions of $83.2 \%$ and the lowest number are respondents with HR positions of $2.1 \%$.

\subsection{Variable Description}

Respondent's assessment on turnover intention explained that the desire to leave the organization in the coming months is considered very high by the respondent and is also the highest indicator in reflecting the variable turnover intention, judging by the highest loading factor value. Working conditions are the highest indicators of job satisfaction with very low ratings. This shows that employees do not feel satisfaction at work plus that the indicator is the most powerful gauge in measuring job satisfaction. Competence is an indicator that is considered the best in perceiving organizational trust. However, the strongest indicator in measuring organizational confidence variables is respondents' perceptions of attention for employees. The last one, procedural justice is 
considered best by respondents about organizational justice, but distributive justice is an indicator that measures the most strongly variable organizational justice.

\subsection{Structural Equation Model-Partial Least Square (SEM-PLS)}

The data analysis method uses the structural equation model-partial least square (SEM-PLS) assisted by the SmartPLS 02 program. The results of the analysis shown in Table 1 consist of description of variables, outer models or measurement models.

\subsubsection{Outer Model or Measurement Model}

\subsubsection{Validity test}

Based on the results of the loading factor calculation, it can be interpreted that all indicators have a loading factor value above 0.5 , so it is said that convergent validity is high. Likewise, with discriminant validity, by using the results of cross loading calculations, it is found that each indicator has the closest relationship to each variable, (indicated by numbers in bold). This can be interpreted that the discriminant validity is high.

Table 1. Mean, Loading Factor, Cross Loading

\begin{tabular}{|c|c|c|c|c|c|c|c|}
\hline \multirow[t]{2}{*}{ Variable } & \multirow[t]{2}{*}{ Indicator } & \multirow[t]{2}{*}{ Mean } & \multirow{2}{*}{$\begin{array}{l}\text { Loading } \\
\text { Factor }\end{array}$} & \multicolumn{4}{|c|}{ Cross Loading } \\
\hline & & & & $\mathrm{TI}$ & JS & OT & OJ \\
\hline \multirow[t]{4}{*}{$\mathrm{TI}$} & The desire of leaving & 4.290 & 0,764 & 0.764 & -0.22 & -0.144 & -0.245 \\
\hline & The desire to find other jobs & 4.171 & 0,769 & 0.769 & -0.402 & -0.218 & -0.413 \\
\hline & Desire to leave the & 4.332 & 0,826 & 0.826 & -0.377 & -0.221 & -0.427 \\
\hline & $\begin{array}{l}\text { organization in the coming } \\
\text { months }\end{array}$ & & & & & & \\
\hline \multirow[t]{6}{*}{ JS } & Compensation & 1.458 & 0,751 & -0.393 & 0.751 & 0.284 & 0.627 \\
\hline & Supervision & 1.400 & 0,734 & -0.471 & 0.734 & 0.264 & 0.929 \\
\hline & The work itself & 1.600 & 0,678 & -0.171 & 0.678 & 0.762 & 0.243 \\
\hline & Relationships with coworkers & 1.653 & 0,752 & -0.209 & 0.752 & 0.724 & 0.327 \\
\hline & Work condition & 1.758 & 0,779 & -0.217 & 0.779 & 0.747 & 0.351 \\
\hline & $\begin{array}{l}\text { Opportunity to get a status } \\
\text { change }\end{array}$ & 1.628 & 0,667 & -0.233 & 0.667 & 0.608 & 0.195 \\
\hline \multirow[t]{5}{*}{ OT } & Competency & 1.811 & 0,579 & -0.139 & 0.456 & 0,579 & 0.527 \\
\hline & Openness and honesty & 1.600 & 0,833 & -0.152 & 0.617 & 0,833 & 0.829 \\
\hline & Attention for employees & 1.700 & 0,947 & -0.217 & 0.779 & 0,947 & 0.243 \\
\hline & Reliability & 1.695 & 0,946 & -0.269 & 0.709 & 0,946 & 0.327 \\
\hline & Identification & 1.747 & 0,857 & -0.257 & 0.581 & 0,857 & 0.351 \\
\hline \multirow[t]{3}{*}{ OJ } & Distributive Justice & 1.453 & 0,929 & -0.471 & 0.734 & 0.708 & 0,929 \\
\hline & Procedural Justice & 1.737 & 0,811 & -0.423 & 0.575 & 0.248 & 0,811 \\
\hline & Interactional Justice & 1.389 & 0,811 & -0.312 & 0.562 & 0.303 & 0,811 \\
\hline
\end{tabular}

Information:

$\mathrm{TI}=$ Turnover Intention

JS = Job Satisfaction

OT = Organizational Trust

OJ = Organizational Justice

Source: Data processing results SmartPLS 02, 2019. 


\subsubsection{Reliability Test}

This test is done by conducting composite reliability and Cronbach's alpha tests. If all latent variable values have a Composite Reability or Cronbach alpha value of $\geq 0.7$, it means that the construct has good reliability or the questionnaire is used as a tool in the study. Based on the calculation results in Table 2, it is found that each variable has a reliability value greater than 0.7 , so it is said that the reliability is very good, the questionnaire is reliable and consistent.

Table 2. The Test Result of Composite Reability dan Cronbach's Alpha

\begin{tabular}{l|c|c|c}
\hline \multicolumn{1}{c|}{ Variable } & Composite Reability & Cronbach's Alpha & Keterangan \\
\hline Job Satisfaction & 0.871 & 0.846 & Reliable \\
Organizational Trust & 0.923 & 0.894 & Reliable \\
Organizationla Justice & 0.888 & 0.811 & Reliable \\
Turnover Intentions & 0.830 & 0.702 & Reliable \\
\hline
\end{tabular}

Source: Data processing results SmartPLS 02, 2019.

\subsubsection{Structural Model or Inner Model}

\subsubsection{Goodness of Fit Model Test}

This test is done using the coefficient of determination or R-Square and Qsquare. From the calculation results found that the value of R-Square and Qsquare is 0.549 or $54.9 \%$. This means that the variables of job satisfaction, organizational trust, and organizational justice can contribute to the variable turnover intention of 0.549 or $54.9 \%$, so that the model density is said to be relatively appropriate.

\subsubsection{Hypothesis testing}

Hypothesis testing is done by testing the significance if the T-count (Tstatistic) is greater than the T-table at alpha $0.05(5 \%)=1.96$, or vice versa. In addition, it can also be seen from the $P$-value, if it is smaller than alpha 0.05 then the hypothesis is accepted, or vice versa.

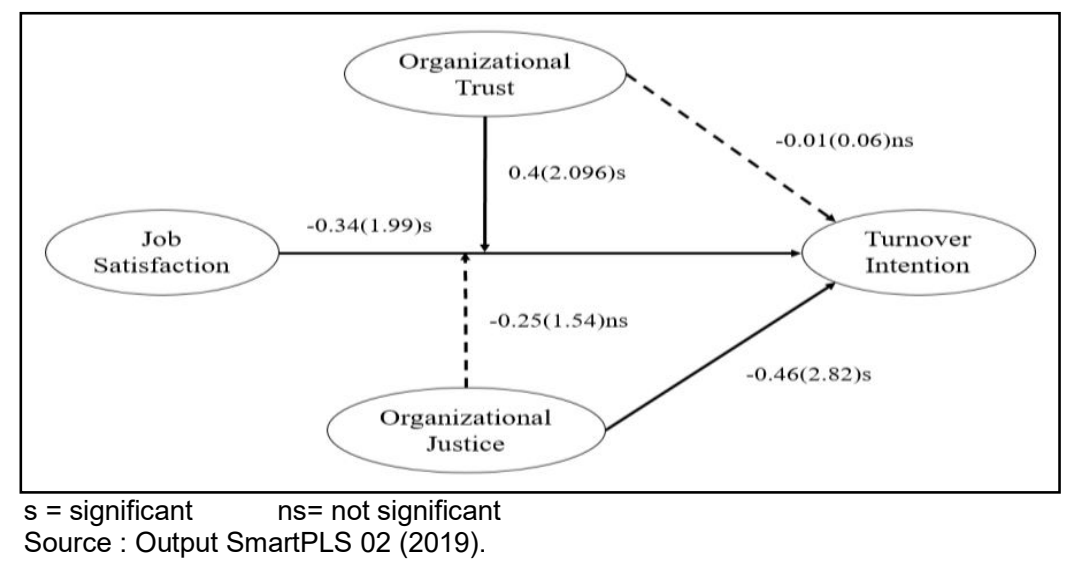

Figure 1. Structural Model Result 
Table 3. Hypothesis Testing Results

\begin{tabular}{c|l|l|l|c|c}
\hline H & Relationship between Variables & $\begin{array}{l}\text { Original } \\
\text { Sample }\end{array}$ & T Statistic & $\begin{array}{c}\mathbf{P} \\
\text { Values }\end{array}$ & $\begin{array}{c}\text { Accept/reject } \\
\text { significance }\end{array}$ \\
\hline H1 & $\begin{array}{l}\text { Job Satisfaction } \rightarrow \text { Turnover Intention } \\
\text { Organizational Trust } \rightarrow \text { Turnover } \\
\text { Intention }\end{array}$ & -0.335 & 1.999 & 0.045 & $\begin{array}{c}\text { Supported } \\
\text { Not } \\
\text { supported }\end{array}$ \\
H3 & $\begin{array}{l}\text { Job Satisfaction*Organizational Trust } \\
\rightarrow \text { Turnover Intention }\end{array}$ & 0.400 & 2.096 & 0.039 & Supported \\
H4 & $\begin{array}{l}\text { Organizational Justice } \rightarrow \text { Turnover } \\
\text { Intention } \\
\text { Job Satisfaction*Organizational } \\
\text { Justice } \rightarrow \text { Turnover Intention }\end{array}$ & -0.455 & 2.819 & 0.006 & Supported \\
H5 & -0.248 & 1.542 & 0.126 & $\begin{array}{c}\text { Not } \\
\text { supported }\end{array}$ \\
\hline
\end{tabular}

Source: Data processing results SmartPLS 02, 2019.

Based on the results of hypothesis testing, as shown in Table 3 and Figure 1, it appears that satisfaction has a negative effect on turnover intention while organizational confidence has no effect on tunover intention. However, the interaction of job satisfaction and organizational trust as a moderating variable affects turnover intention. Is is said to be the belief of organizations as pure moderation. This means that organizational trust is purely a moderation variable and does not act as a predictor.

Meanwhile, organizational justice has a negative effect on turnover intention, but as a moderator it has no effect on tunover intention so it is said that organizational justice is as a potential moderation. The existence of organizational justice variable does not function as a moderating variable, it only functions as a predictor.

\subsection{Discussion}

Based on hypothesis testing in research done shows that job satisfaction has a negative effect on turnover intention, $\mathrm{H} 1$ is received. The higher the dissatisfaction felt by employees, the higher the desire of the employees to quit the job. Satisfaction in low working conditions, which reflects the most dominant job satisfaction, drives the higher level of employee dissatisfaction to the higher turnover intention which is reflected most dominantly by the desire to leave the organization in the coming months. The results of this study are in line with the social exchange theory proposed by Homans (1958) saying that when a person's actions get an expected reward, especially a reward greater than expected, he tends to behave pleasantly and the results of these actions are more valuable to him, and vice versa. These results support the research of Li et al. (2019), Zhang et al. (2018), Simone et al. (2017), and Soelton \& Atnani (2018) which proves that job satisfaction has a negative effect on turnover intention. However, this study does not support the research of Yuda \& Ardana (2017), Sukmana et al. (2016) which proves that job satisfaction does not affect turnover intention. 
The results of the study prove that organizational trust has no significant effect on turnover intention, $\mathrm{H} 2$ is rejected. Trust in an organization that decreases does not affect in the increasing turnover intention. Organizational attention for employees is the most powerful indicator in measuring the variable of organizational trust but does not affect the decreasing turnover intention. These results support Daniel's (2012) study which proves that organizational trust does not affect turnover intention, but it does not support Jiang \& Shen (2017) which proves that organizational trust negatively affects turnover intention. So trust to anything in the company has very low result but still does not cause employees to immediately decide to leave, just a desire but does not take action to leave the company. The necessity of life is the factor that makes employees stay in the company.

The interaction of job satisfaction and organizational trust as a moderating variable affects turnover intention, $\mathrm{H} 3$ is received. The existence of organizational trust is needed to strengthen the effect of higher job satisfaction in order to further decrease the desire to leave work. Social exchange theory can be used to explain the results of this study. That the employee who has high expectations of the organization as an embodiment that he believes in the organization is needed to strengthen the effect of increasing satisfaction in order to further withhold employees who have the desire to leave the job.

The results find that organizational justice has a negative effect on turnover intention, $\mathrm{H} 4$ is received. The higher the injustice felt by the employee, the higher the level of employee desire to leave. Distributive justice is an indicator that measures the most powerful variable of organizational justice. If distributive justice is perceived low by employees, it will have an impact on the increasing desire to leave employees. This study supports the research of Suta \& Supartha (2016), Yunita \& Putra (2015), and Wiratama \& Siana (2015) which prove that organizational justice has a negative effect on turnover intention.

The interaction of job satisfaction and organizational justice as a moderating variable does not affect turnover intention. This means that organizational justice cannot strengthen the effect of job satisfaction in suppressing turnover intention.

\section{CONCLUSION}

Job satisfaction has a negative effect on turnover intention, meaning that the decrease of employee job satisfaction causes the increase of turnover intention. Organizational trust does not have a significant effect on turnover intention which means that organizational trust that increases or decreases does not cause that turnover intention to increase or decrease. The interaction of job satisfaction and organizational trust as a moderating variable affects turnover intention. The existence of organizational trust is needed to strengthen the effect of higher job satisfaction in order to further decrease the desire to leave the work. Organizational justice has a negative effect on turnover intention. The higher the injustice felt by the employee, the higher the level of employee desire to leave. The interaction of job satisfaction and organizational justice as a moderating variable 
does not affect turnover intention. This means that organizational justice cannot strengthen the effect of job satisfaction in suppressing turnover intention.

For further researchers, it is recommended to add the variables of transactional leadership, organizational commitment, and workload so that the research results will be more accurate.

\section{REFERENCES}

Abdurrahim, Anisah, H.U. (2015). Pengaruh Kepuasan Kerja dan Komitmen Organisasi terhadap Turnover Intention Karyawan Studi pada PT. Bank Perkreditan Rakyat Mitratama Arthabuana. Jurnal Wawasan Manajemen. Vol. 3, No. 3.

Andries, D. (2012). Analisis Pengaruh Job Insecurity, Komitmen Organisasi, Kepuasan Kerja, Dan Kepercayaan Organisasi Terhadap Turnover Intention Pada PT. Utama Jaya Perkasa. Diakses pada tanggal 14-Juli-2018.

Arifin, Z.S., Troena, A.E., Thoyib A., Nimran U. 2010. Pengaruh Karakteristik Individu, Stress Kerja, Kepercayaan Organisasional Terhadap Intention to Stay Melalui Kepuasan Kerja dan Komitmen Organisasi (Studi pada Dosen Tetap Yayasan PTS Makassar). Jurnal Aplikasi Manajemen. 8, (3).

Arikunto, S. 2010. Prosedur penelitian Suatu Pendekatan Praktik. Edisi Revisi. Jakarta: PT. Rineka Cipta.

Badriyah, M. 2015. Manajemen Sumber Daya Manusia, Cetakan 1. Bandung: Pustaka Setia.

Cahayu, A.P. \& Adnyani, A.G. 2015. Pengaruh Keadilan Organisasi Terhadap Kepuasan Kerja dan Organizational Citizenship Karyawan Toko Nyoman. EJurnal Manajemen Unud. 4, (11).

Chung, E.K., Jung, Y., Shon, Y.W., 2017, A moderated mediation model of job stress, job_satisfaction, and turnover_intention for airport security screeners Safety Science, 98, 89-97.

Cipta, H. 2016. Pengaruh Kepercayaan dan Kepuasan Kerja Terhadap Turnover Guru SD Swasta di Kecamatan Jatiasih Kota Bekasi. Jurnal Pedagogik. Vol. 4, No. 2.

Cropanzano, R, Bowen, D.E., \& Gilliland, Stephen. W. 2007. The Management Of Organizational Justice. Academy Of Management Perspectives. Vol. 21. No. 4.

Faza, W.A., Handoyo, S., 2013, Kepercayaan Organisasi Pada Karyawan Kebun Binatang Surabaya. Jurnal Psikolog Industri dan Organisasi. Vol. 2, No. 3.

Ghozali, I. \& Latan, H. 2015. Partial Least Squares, Konsep, Teknik dan Aplikasi Menggunakan Program Smartpls 3.0 Untuk Konsep Penelitian Empiris. Edisi 2. Semarang: Badan Penerbit Universitas Diponegoro. 
Griffin, Moorhead. 2010. Organizational Behaviori Managing People and Organizational Ninth Edition South-Westren Cencage Learning.

Gul, H., Rehman, Z., Usman M., Hussain, Sr. 2015. The Effect of Organizational Justice on Employee Turnover Intention with The Mediating Role of Emotional Exchaustion in the Banking Sector of Afghanistan. International Journal of Management Sciences. Vol. 5, No. 4.

Hasibuan, M. 2009. Manajemen Sumber Daya Manusia, Cetakan 9. Jakarta: Bumi Aksara.

Hidayati, N., Trisnawati, D. 2016. Pengaruh Kepuasan Kerja dan Stress Kerja terhadap Turnover Intentions Karyawan Bag Marketing. PT Wahana Sahabat Utama. Jurnal Eksis. Vol. 11, No. 1.

Hwei, S., Santosa, E.C. 2012. Pengaruh Keadilan Prosedural dan Keadilan Distributif terhadap Komitmen Organisasi. Jurnal Dinamika Ekonomi Dan Bisnis. Vol. 9, No. 2.

Indrasari, M. 2017. Kepuasan Kerja dan Kinerja Karyawan. Edisi Pertama. Yogyakarta: Indomedia Pustaka.

Iqbal S., Ehsan, S., Rizwan, M., Noreen, M. 2014. The Impact of Organizational Commitment, Job Satisfaction, Job Stess and Leadership Support on Turnover Intention In Educational Institutes. Internationl Journal of Human Resource Studies. Vol. 4, No.2.

Jiang, H., Shen, H., 2018, Supportive organizational environment, work-life enrichment, trust and turnover intention: A national survey of PRSA membership, Public Relations Review, 44, (5), 681-689. Doi: 10.1016/j.pubrev.2018.08.007

Li, N., Zhang, L., Xiao, G., Chend, J., Lu, Q., 2019, The relationship between workplace violence, job satisfaction and turnover intention in emergency nurses, International Emergency Nursing, $\underline{45},(7), \quad 50-55$, doi: 10.1016/j.ienj.2019.02.001

Kaswan. 2012. Manajemen Sumber Daya Manusia untuk Keunggulan Bersaing Organisasi. Edisi Pertama. Yogyakarta: Graha Ilmu.

Kristanto, H. 2015. Keadilan Organisasional, Komitmen Organisasional dan Kinerja Karyawan. Jurnal Manajemen dan Kewirausahaan. Vol. 17, No.1.

Mangkunegara, A.P. 2016. Manajemen Sumber Daya Manusia Perusahaan. Cetakan Kesebelas. Remaja Rosdakarya. Bandung.

Martono, S., Fadzilah. 2016. Pengaruh Ketidakamanan Kerja, Komitmen Organisasional dan Kepercayaan Organisasional pada Keinginan Berpindah. Management Analysis Journal 5 (3).

Pawesti, R., Wikansari, R. 2016. Pengaruh Kepuasan Kerja terhadap Intensi Turnover Karyawan di Indonesia. Jurnal Ecopsy. Vol. 3, No. 2. 
Poeh, G.C., Soehari T.D. (2017). Pengaruh Komitmen Organisasi, Kepuasan Kerja dan Stres Kerja terhadap Turnover Intention Guru Sekolah X di Tangerang, Jurnal SWOT, 12, (2), 224-238.

Putri, K.F. 2015. Pengaruh Keadilan Organisasional dan Motivasi Kerja terhadap Kepuasan Kerja Karyawan Toko Buku Uranus. Agora. Vol. 3, No. 2.

Rivai, V. 2009. Manajemen Sumber Daya Manusia Untuk Perusahaan Dari Teori ke Praktik. Jakarta. Edisi Kedua: Raja Grafindo Persada.

Saeed, I., Waseem, M., Sikander, S. \& Rizwan, M. 2014. The relationship of Turnover intention with job satisfaction, job performance, Leader member exchange, Emotional intelligence and organizational commitment. International Journal of Learning \& Development. Vol. 4, No. 2.

Sanusi, A. 2011. Metode Penelitian Bisnis. Salemba Empat. Jakarta.

Sartika, D. 2014. Pengaruh Kepuasan Kerja dan Kepemimpinan Transformasional terhadap Keinginan Keluar Karyawan dengan Komitmen Organisasi Sebagai Variabel Mediasi (Studi Kasus Di CV. Putra Tama Jaya). Management Analysis Journal. Vol. 3, No. 2.

Serin, A.E., Balkan, M. O. 2014. The Relationship between Trust, Turnover Intention and emotions An Application. The Journal of Knowledge Economy \& Knowledge Management. Vol. 9, No. 2

Simone, S.D., Planta, A., Cicotto, G, 2017, The role of job satisfaction, work engagement, self-efficacy and agentic capacities on nurses' turnover intention and patient satisfaction, Applied Nursing Research, 39, (2), 130 140, https://doi.org/10.1016/j.apnr.2017.11.004

Soelton, M., Atnani, M. 2018, How Work Environment, Work Satisfaction, Work Stress on the Turnover Intention affect University Management, Jurnal Manajemen Bisnis Indonesia, 5 (3), 439-448.

Stephen, P.R. \& Timothy A.J. 2015. Perilaku Organisasi (Ratna Saraswati dan Febriella Sirait, Penerjemah, Ed. Ke-16). Jakarta: Salemba Empat.

Sugiyono. 2014. Metode Penelitian Kuantitatif, Kualititatif dan R\&D. Alfabeta. Bandung.

Sukmana 2016. Analisis Job Insecurity dan Kompensasi terhadap Turnover Intention Melalui Kepuasan Kerja karyawan PT. Wijaya Panca Sentosa Food Sidoarjo. Diakses pada tanggal 15-Juli-2018.

Suta, A.W. dan Supartha, Gede. I.W. 2016. Pengaruh Keadilan Organisasi terhadap Kepuasan Kerja dan Keinginan Keluar Karyawan pada Alila Manggis Hotel Karang Asem Bali. E-Jurnal Manajemen Unud. Vol. 5, No. 4. 
Wiratama, D.G. dan Suana, I.W. 2015. Pengaruh Keadilan Organisasi terhadap Kepuasan Kerja dan Turnover Intention pada Karyawan the Jayakarta Bali. E-Jurnal Manajemen Unud. Vol. 4, No. 11.

Wirawan. 2015. Manajemen Sumber Daya Manusia Indonesia: Teori, Psikologi, Hukum, Ketenagakerjaan, Aplikasi dan Penulisan: Aplikasi dalam Organisasi Bisnis, Pemerintahan dan Pendidikan. PT. Rajagrafindo Persada. Jakarta.

Widodo, R. 2010. Analisis Pengaruh Keamanan Kerja dan Komitmen Organisasional Terhadap Turnover Intention serta Dampaknya pada Karyawan Outsourcing. Tesis. Semarang: Universitas Diponegoro. Diakses pada tanggal 16-Desember-2017.

Yuda, I.B. dan Ardana I.K. 2017. Pengaruh Kepuasan Kerja dan Stres Kerja Terhadap Turnover Intention pada Karyawan Hotel holiday Inn Express. EJurnal Manajemen Unud. Vol. 6, No. 10

Yunita. K.L. dan Putra M.S. 2015. Pengaruh Keadilan Organisasi dan Lingkungan Kerja tTerhadap Turnover Intention. E-Jurnal Manajemen Unud. Vol. 4, No.5.

Zhang, X., Ma, L., Xu, B., Feng Xu, F., 2019, How social media usage affects employees' job satisfaction and turnover intention: An empirical study in China, Information \& Management, 56, (6), 103-136. DOI: 10.1016/j.im.2018.12.004. 